\title{
Analisis Asam Lemak Bebas dan Kolesterol pada Minyak Kelapa Hasil Fermentasi
}

\author{
Diana Hernawati ${ }^{* 1}$, Jirana ${ }^{2}$ \\ ${ }^{1}$ Universitas Siliwangi Tasikmalaya \\ ${ }^{2}$ Universitas Sulawesi Barat \\ e-mail: ${ }^{1}$ hernawatibiologi@unsil.ac.id, ${ }^{2}$ jirana@unsulbar.ac.id
}

\begin{abstract}
Abstrak
Minyak kelapa merupakan zat makanan yang diperlukan sebagai sumber kalori. Dalam bidang pangan, selain berfungsi sebagai sumber energi bagi tubuh juga berguna sebagai media penghantar panas dan penambah cita rasa. Penelitian ini bertujuan untuk mengetahui kadar asam lemak bebas dan kolesterol pada minyak kelapa hasil fermentasi. Penelitian ini merupakan penelitian deskriptif kuantitatif karena hanya melihat rendemen dan menguji kadar asam lemak bebas dan kolesterol yang terkandung dalam minyak kelapa yang dibuat dari kelapa hijau (Cocos nucivera L. var viridis) dengan cara fermentasi menggunakan Saccharomyces cerevisiae. Uji kadar asam lemak menggunakan cara titrasi dengan basa KOH dan uji kualitatif kolesterol menggunakan uji Liebermann-Burchard. Untuk ketelitian data penelitian dilakukan tiga kali. Hasil penelitian ini menyimpulkan rendemen minyak yang diperoleh dari hasil pembuatan minyak kelapa dengan cara fermentasi sebesar 28,78\%; kadar asam lemak bebas adalah 0,87\%; dan tidak mengandung kolesterol.
\end{abstract}

Kata kunci : Asam lemak bebas, fermentasi, kolesterol, minyak kelapa

\section{PENDAHULUAN}

Kelapa (Cocos nucifera L.) merupakan salah satu dari sekian banyak biji tanaman yang dapat digunakan dalam pembuatan minyak. Minyak yang terbuat dari kelapa banyak digunakan masyarakat sebagai minyak goreng. Minyak kelapa merupakan minyak yang diperoleh dari kopra (daging buah kelapa yang dikeringkan) atau dari perasan santannya. Kandungan minyak pada daging buah kelapa tua diperkirakan mencapai $30-35 \%$, atau kandungan minyak dalam kopra mencapai $63-72 \%$. Minyak kelapa sebagaimana minyak nabati lainnya merupakan senyawa trigliserida yang tersusun atas berbagai asam lemak dan $90 \%$ di antaranya merupakan asam lemak jenuh. Selain itu minyak kelapa yang belum dimurnikan juga mengandung sejumlah kecil komponen bukan lemak seperti fosfatida, gum, sterol (0,06-0,08\%), tokoferol $(0,003 \%)$, dan asam lemak bebas $(<05 \%)$ dan sedikit protein dan karoten (Rindengan dan Novarianto, 2005). Sterol berfungsi sebagai stabilizer dalam minyak dan tokoferol sebagai antioksidan (Xu, et al,. 2015).

Minyak nabati memiliki sifat dan ciri tersendiri yang sangat ditentukan oleh struktur asam lemak pada rangkaian trigliseridanya. Minyak kelapa kaya akan asam lemak berantai sedang $\left(\mathrm{C}_{8}-\mathrm{C}_{14}\right)$, khususnya asam laurat dan asam meristat. Adanya asam lemak rantai sedang ini (median chain fat) yang relatif tinggi membuat minyak kelapa mempunyai beberapa sifat daya bunuh terhadap beberapa senyawa yang berbahaya di dalam tubuh manusia. Sifat inilah yang didayagunakan pada pembuatan minyak kelapa murni (virgin coconut oil) (Rahmadi, et al., 2013). 
Pembuatan minyak kelapa secara secara tradisional dilakukan dengan pemanasan pada suhu tinggi. Pembuatan minyak kelapa secara tradisional ini banyak menimbulkan kerugian. Sebagai contoh, pemanasan yang tinggi dapat mengubah struktur minyak serta menghasilkan warna minyak kurang baik. Hal ini seperti yang dijelaskan oleh Utami (2008), bahwa pembuatan minyak kelapa kasar (crude oil) yang terdiri dari rendering dan pengepresan, cara ini kurang maksimal hasilnya.

Industri minyak kelapa menggunakan kopra (daging kelapa yang dikeringkan dengan kadar air $<3 \%$ ) dengan metode pressing. Pada pengolahan minyak dengan metode ini, minyak hasil ekstraksi harus diolah lagi untuk meningkatkan kualitasnya. Di samping itu rendemen minyak kelapa kopra dapat turun sampai $40 \%$ yang disebabkan oleh tumbuhnya jamur seperti Rhizopus sp., Aspergillus flavus, Aspergilus niger, Penicillium glaucum" (Andaka \& Arumsari, 2016; Candra, 2006). Dengan alasan itu maka pengolahan minyak kelapa dari bahan segar merupakan alternatif agar dapat diperoleh produksi minyak kelapa yang rendemen dan kualitas tinggi. Untuk meningkatkan efisiensi pembuatan minyak telah dikembangkan berbagai cara pembuatan minyak kelapa secara fermentasi dengan bahan baku santan dan menggunakan mikroorganisme.

Proses fermentasi karbohidrat akan terbentuk asam-asam organik yang dapat menurunkan $\mathrm{pH}$ pada krim kelapa sehingga akan merusak protein. Menurut Pelczar dan Chan (Soeka, et.al,. 2008) bahwa proses ekstraksi minyak secara fermentasi melibatkan enzim-enzim pemecah emulsi santan. Aktivitas enzim dipengaruhi oleh konsentrasi substrat, konsentrasi enzim, pH, suhu dan lamanya reaksi enzimatik (Hossain, et al., 2017). Selanjutnya Soeka, et.al,. (2008) menambahkan bahwa biakan mikroba yang digunakan diharapkan memiliki aktivitas protelitik, amiolitik, dan lipolitik yang berperan dalam menghidrolisis protein, karbohidrat, dan lemak.

Melalui berbagai penelitian juga ditemukan bahwa minyak yang dihasilkan dengan cara fermentasi atau yang dikenal dengan sebutan minyak kelapa murni (virgin coconut oil) memiliki mutu yang lebih baik menurut SII (Standar Industri Internasional) dibandingkan dengan minyak hasil masak langsung. Keuntungan lain dari pembuatan minyak dengan cara fermentasi adalah tidak membutuhkan bahan bakar yang cukup banyak.

\section{METODE PENELITIAN}

Penelitian ini difokuskan pada minyak kelapa hasil fermentasi yang dilihat rendemennya dan dianalis kadar asam lemak bebas dan kolesterolnya. Perhitungan rendemen minyak kelapa yang dihasilkan adalah untuk mengetahui berapa banyak minyak kelapa yang dihasilkan dari sejumlah kelapa parut yang dibuat. Perhitungan rendemen dilakukan untuk menganalisis keuntungan ekonomis pembuatan minyak kelapa dengan cara fermentasi.

Kadar asam lemak bebas (angka asam) dilakukan dengan cara titrasi menggunakan basa (kalium hidroksida) dan analisis kadar kolesterol dalam minyak kelapa diawali dengan uji kualitatif menggunakan uji Liebermann-Burchard. Teknik analisis data untuk perhitungan rendemen untuk setiap minyak kelapa yang dihasilkan dihitung dengan rumus :

Rendemen $=\frac{\text { Berat Minyak Kelapa yang Dihasilkan }(\mathrm{gr})}{\text { Berat Krim }(\text { gram })}$ X $100 \%$

Sedangkan perhitungan kadar asam lemak bebas (angka asam) untuk setiap pengujian dihitung kadar asam lemak bebas dengan persamaan:

Bilangan Asam $=\frac{\mathrm{ml} \mathrm{KOH} \times \text { Normalitas } \mathrm{KOH} \times 56,1}{\text { Berat sampel }(\text { gram })}$ 


\section{HASIL DAN PEMBAHASAN}

\subsection{Rendemen Minyak Kelapa yang Dihasilkan}

Rendemen minyak kelapa yang dihasilkan dari tiga ulangan percobaan diperoleh hasil yang berbeda walaupun perlakuan yang diberikan sama, datanya seperti dapat dilihat pada Gambar 1.

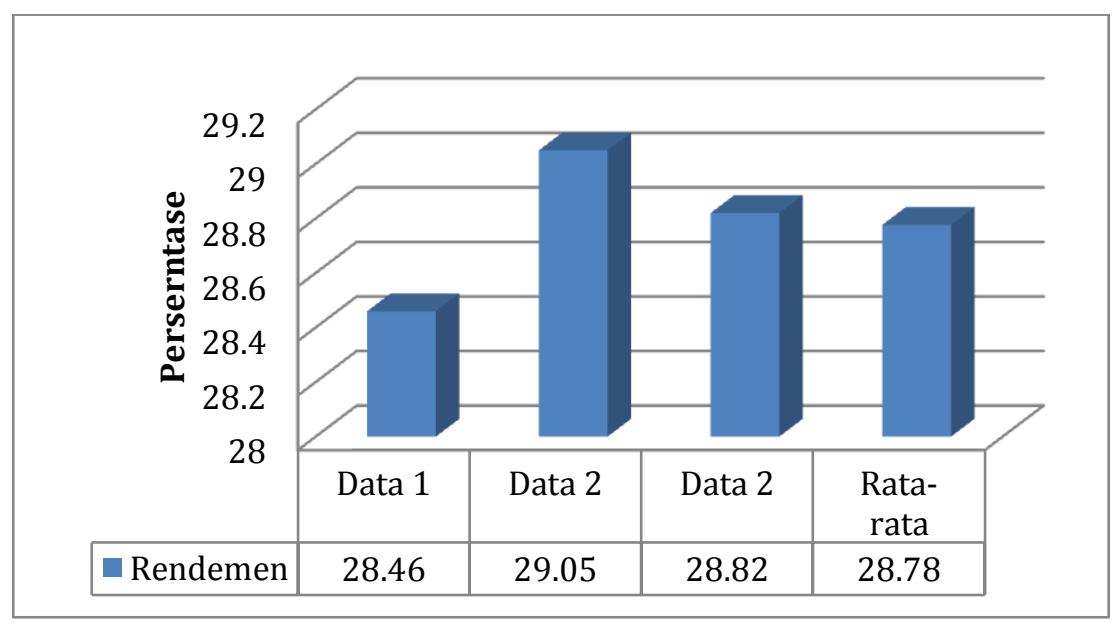

Gambar 1 rendemen minyak kelapa yang dihasilkan

Pada Gambar 1 dapat dilihat bahwa rendemen minyak yang paling besar adalah yang diperoleh pada ulangan ke dua, dan rata-rata rendemen yang dihasilkan hanya 28,78\%. Angka ini belum maksimum karena secara umum rendemen minyak kelapa dari kelapa segar adalah $35 \%$. Sejumlah faktor penyebabnya dapat dimungkinkan berupa santan yang diperoleh dari kelapa yang kurang tua, hal ini dirasakan pada saat peneliti memeras kelapa parut untuk dipisahkan santannya. Seharusnya untuk membuat minyak kelapa digunakan kelapa tua karena kandungan kalori dan lemaknya mencapai maksimal sehingga sangat membantu proses pemisahan dan rendemen minyak yang diperoleh juga lebih banyak dibandingkan kelapa muda. Kadar protein terbesar terkandung dalam endosperm (daging buah) kelapa setengah tua, sedangkan kelapa tua mengandung kadar protein, kolesterol dan FFA yang paling rendah. Faktor lainnya adalah berupa ampas kelapa hasil perasan masih ditemukan kadar lemak cukup tinggi, sehingga untuk meningkatkan proses penyantanan secara lebih efisien dapat digunakan alat penghancur, agar seluruh kandungan lemak yang masih tersisa dalam ampas kelapa dapat diekstraksi secara maksimum. Derajat kerusakan sel-sel endosperm kelapa sebagai akibat proses penyantanan yang baik, menyebabkan bahan yang terkandung dalam sel akan terlarut termasuk partikel lemak dan minyak. Proses penyantanan akan menjadi lebih efisien dan pemisahan komponen minyak dari komponen lainnya menggunakan aktivitas enzim mikrobia secara fermentasi menjadi lebih efektif.

\subsection{Kadar Asam Lemak Bebas}

Perhitungan bilangan asam diperoleh data sebagaimana dapat dijelaskan pada Gambar 2 di bawah ini : 


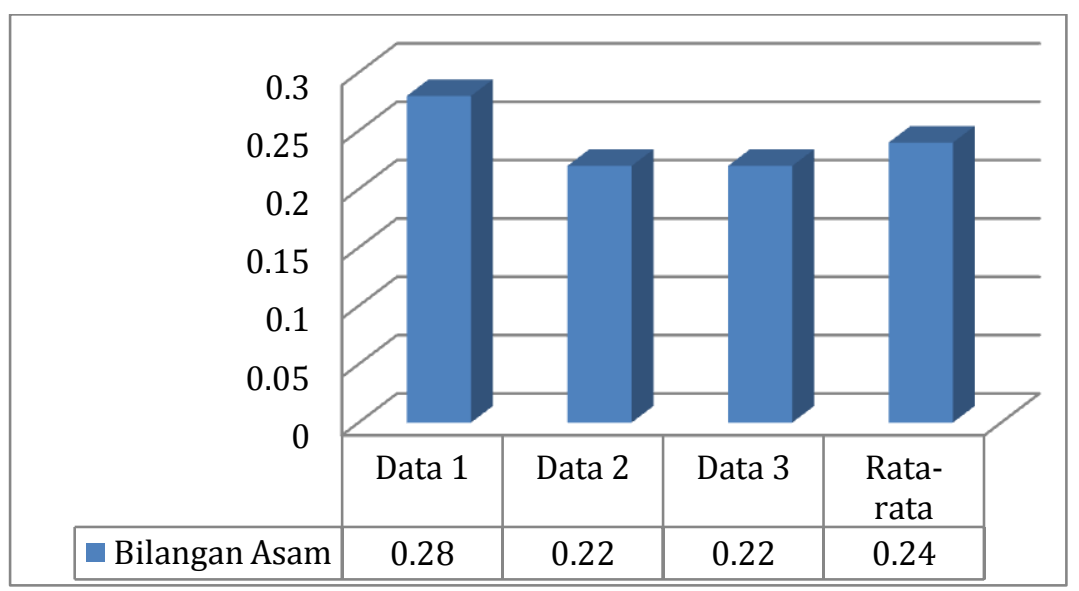

Gambar 2 bilangan asam dalam minyak kelapa

Bilangan asam menunjukkan kandungan asam lemak yang terkandung dalam minyak kelapa. Untuk lebih menspesifikasi kandungan asam lemak yang terkandung selanjutnya dihitung kadar asam lemak bebas dan diperoleh data sebagaimana digambarkan pada Gambar 3.

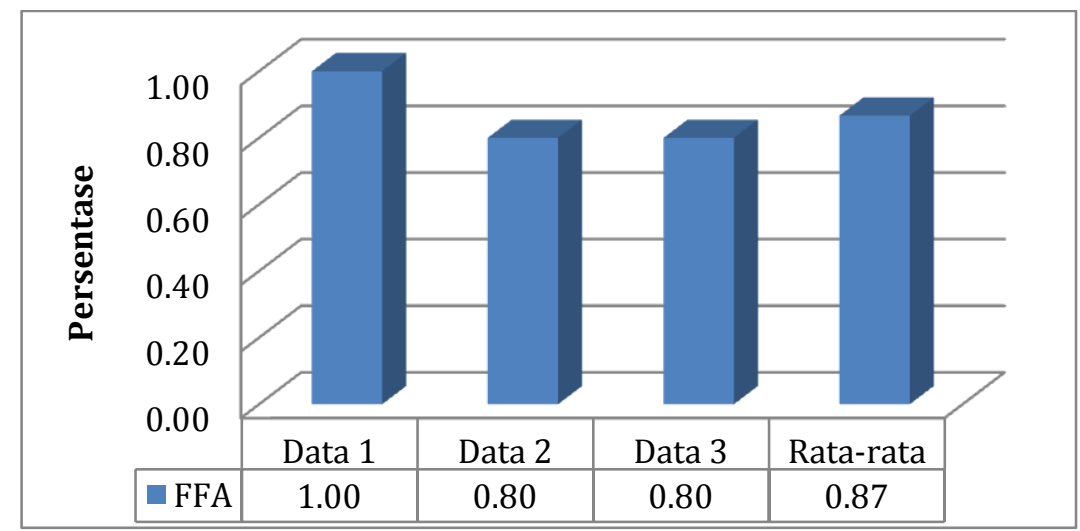

Gambar 3 grafik ffa yang terkandung dalam minyak kelapa

Kandungan utama minyak kelapa adalah $92 \%$ asam lemak jenuh, $6 \%$ asam lemak tak jenuh tunggal, dan $2 \%$ asam lemak tak jenuh majemuk. Dari $92 \%$ asam lemak jenuh yang terdapat dalam minyak kelapa, 64\% merupakan asam lemak jenuh rantai medium (medium chain saturated fatty acid = MCSFA) yang terdiri dari asam laurat (C12), asam kaprat (C10), dan asam kaprilat (C8). Sementara itu asam lemak jenuh rantai panjang terdiri dari asam palmitat, asam stearat, asam arakhidat serta asam lemak tak jenuh rantai panjang terdiri dari asam palmitoleat, asam oleat dan asam linoleat. Dalam penentuan kadar asam lemak bebas minyak kelapa hasil fermentasi ini menggunakan berat molekul asam laurat karena kandungan asam lemak bebas asam laurat paling besar sekitar 50,50\% dari seluruh kandungan asam lemak bebas (Wibowo, 2005).

Penentuan kadar asam lemak bebas dengan menggunakan metode titrasi. Titrasi merupakan suatu metoda untuk menentukan kadar suatu zat dengan menggunakan zat lain yang sudah diketahui konsentrasinya. Setelah penimbangan sampel ditambahkan alkohol, penambahan alkohol adalah untuk melarutkan minyak dalam sampel agar dapat bereaksi dengan basa alkali. Karena alkohol yang digunakan adalah untuk melarutkan minyak, sehingga alkohol yang digunakan konsentrasinya berada di kisaran 95-96\%, karena alkohol $95 \%$ 
merupakan pelarut lemak yang baik. Alkohol yang digunakan adalah alkohol netral karena bila kondisi tidak netral, titrasi asam-basa akan berakhir dengan diperoleh data yang salah. Sesuai dengan definisi bilangan FFA itu sendiri yaitu jumlah miligram $\mathrm{KOH}$ atau basa-basa lainnya yang dibutuhkan untuk menetralkan asam-asam lemak. Untuk memanaskan alkohol dapat mempergunakan penangas air karena titik didih alkohol kurang dari air.

Pemberian 5 tetes indikator pp pada penelitian ini adalah sebagai indikator pembuktian bahwa bahan tersebut bersifat asam atau basa. Pada penelitian ini, setelah dititrasi dengan $\mathrm{KOH}$ $0,1 \mathrm{~N}$, larutan alkohol dan minyak kelapa yang telah ditetesi indikator pp berubah warna menjadi merah muda. Hal ini membuktikan bahwa larutan tersebut bersifat basa. Titik akhir titrasi adalah keadaan dimana reaksi telah berjalan dengan sempurna yang biasanya ditandai dengan pengamatan visual melalui perubahan warna indikator. Pada penelitian ini perubahan terjadi menjadi merah lembayung, maka trayek pH-nya sekitar 9-10 (basa).

Rata-rata hasil perhitungan kadar asam lemak bebas adalah 0,87\%, angka ini masih lebih besar dari angka yang seharusnya yaitu $0,1-0,3 \%$. Sejumlah penyebab tingginya angka tersebut adalah pada saat pengocokan di waterbath pengocokan dilakukan secara manual, karena tidak ada alat yang memadai, $\mathrm{KOH}$ yang digunakan bukan $\mathrm{KOH}$ pa tetapi $\mathrm{KOH}$ teknis dan ketelitian peneliti saat melakukan titrasi.

\subsection{Kadar Kolesterol}

Analisis kadar kolesterol dalam minyak kelapa diawali dengan uji kualitatif menggunakan uji Liebermann-Burchard. Pada metode ini apabila sampel mengandung kolesterol maka akan terjadi perubahan warna dari merah menjadi biru kemudian hijau. Bila kolesterol direaksikan dengan asam asetat anhidrid dan asam sulfat pekat dalam lingkungan bebas air, maka akan terbentuk warna hijau-biru yang intens akibat pembentukan polimer hidrokarbon tak jenuh. Kemudian ditambahkan $\mathrm{H}_{2} \mathrm{SO}_{4}$ pekat untuk mengoksidasi sehingga mempercepat terbentuknya warna.

Hasil uji kolesterol setelah tiga kali pengulangan dapat disimpulkan bahwa minyak kelapa yang dibuat dengan cara fermentasi tidak mengandung kolesterol. Hal ini sesuai dengan teori bahwa kolesterol hanya terkandung dalam lemak hewani. Tetapi konsumsi minyak kelapa yang berlebihan juga tetap membahayakan kesehatan. Minyak kelapa mengandung golongan asam-asam lemak tidak jenuh rantai panjang (MUFA/PUFA) berukuran molekul besar-besar yang berbahaya untuk kesehatan. Jika dipakai untuk menggoreng atau dipanaskan, disamping akan mengalami polimerisasi, juga membentuk "asam lemak-trans" dan "radikal bebas" yang bersifat toksik dan karsinogenik. Oleh sebab itu minyak nabati harus diproses terlebih dahulu sebelum diserap oleh dinding usus. Minyak nabati tersebut mula-mula diuraikan menjadi unit asam-asam lemak ukuran kecil melalui proses hidrolisis dan emulsi dengan bantuan cairan empedu dan enzim dari kelenjar pankreas, menjadi unit-unit asam lemak bebas sebagai cikal bakal lipoprotein. Selanjutnya senyawa tersebut mengalami metabolisme dalam hati dan didistribusikan ke seluruh tubuh dalam bentuk energi, kolesterol dan timbunan lemak dalam tubuh. Jadi, semua jenis minyak nabati selain kelapa akan berakhir di dalam tubuh sebagai energi, kolestrol dan timbunan lemak. Kolesterol dan lemak inilah yang sering kali menjadi dasar penyebab berbagai jenis penyakit kronis, degeneratif dan kanker.

Asam lemak trans adalah lemak tidak jenuh yang terbentuk dari sebuah proses hidrogenasi (Ketare, 1986). Proses hidrogenasi adalah proses dimana lemak tidak jenuh (MUFA/PUFA) dipanaskan pada suhu tinggi dan ditambahkan zat hidrogen. Proses ini bertujuan untuk lebih mengentalkan lemak tidak jenuh yang bersifat cair dan mencegahnya agar tidak cepat teroksidasi dan basi. Asam lemak tidak jenuh secara alamiah lebih mudah teroksidasi dan berbau busuk karena tidak memiliki ikatan hidrogen yang penuh. Hal ini sangat berbeda dengan asam lemak jenuh pada minyak kelapa yang lebih tahan terhadap proses oksidasi dan tidak mudah berbau busuk karena memiliki ikatan hidrogen yang penuh. 


\section{KESIMPULAN}

Berdasarkan hasil penelitian dan pembahasan diperoleh beberapa simpulan sebagai berikut :

1. rendemen minyak yang diperoleh dari hasil pembuatan minyak kelapa dengan cara fermentasi diperoleh sebesar $28,78 \%$.

2. kadar asam lemak bebas dalam minyak kelapa hasil fermentasi diperoleh sebesar $0,87 \%$ dan

3. Analisis kualitatif minyak kelapa fermentasi dihasilkan ciri tidak berwarna, berbau harum dan tidak mengandung kolesterol.

\section{DAFTAR PUSTAKA}

Andaka, G., \& Arumsari, S., 2016, Pengambilan minyak kelapa dengan metode fermentasi menggunakan ragi roti, Teknik Kimia, Vol. 10, No. 2.

Candra, K., 2006, Aplikasi Fermentasi Menggunakan Saccharomyces cereviceae pada Krim Kelapa untuk Ekstraksi Minyak, Jurnal Teknologi Pertanian, Vol.1, No. 2, Hal. 68-73.

Hossain, N., Zaini, J. H., \& Mahlia, T. M., 2017, A Review of Bioethanol Production from Plantbased Waste Biomass by Yeast Fermentation, Int J Technol, Vol. 8, No. 1, Hal. 5-18.

Ketare, 1986, Pengantar Teknologi Minyak dan Lemak Pangan, UI Pers, Jakarta.

Rahmadi, A., Abdiah, I., Sukarno, M. D., \& Purnaningsih, T., 2013, Karakteristik Fisikokimia Dan Antibakteri Virgin Coconut Oil Hasil Fermentasi Bakteri Asam Laktat [Physicochemical And Antibacterial Characteristics Of Virgin Coconut Oil Fermented With Lactic Acid Bacteria], Jurnal Teknologi Dan Industri Pangan, Vol. 24, No. 2, Hal. 178.

Rindengan dan Novarianto, 2005, Pembuatan dan Pemanfaatan Minyak Kelapa Murni, Penebar Swadaya, Depok.

Soeka, YS., et.al,. 2008, Analisis Biokimia Minyak Kelapa Hasil Ekstraksi secara Fermentasi, Bioversitas, Vol.9, No. 2, Hal. 91-95.

Utami, IK., 2008, Pengambilan Minyak Kelapa dengan Proses Fementasi Menggunakan Saccharomyces cerevicerae Amobil, Jurnal Penelitian Ilmu Teknik, Vol. 8, No. 2, Hal. 8695.

Wibowo, 2005, VCO dan Pencegahan Komplikasi Diabetes, Pawon Publishing, Jakarta.

Xu, B., Li, P., Ma, F., Wang, X., Matthäus, B., Chen, R., ... \& Zhang, Q. 2015. Detection of virgin coconut oil adulteration with animal fats using quantitative cholesterol by $\mathrm{GC} \times \mathrm{GC}-$ TOF/MS analysis. Food chemistry, No. 178, Hal. 128-135. 